\title{
THE REORGANIZATION OF ECONOMIC ACTIVITIES AND THE PERSPECTIVES OF THE ENDOGENOUS DEVELOPMENT IN THE MINING AREAS FROM GORJ COUNTY
}

\author{
Cristian BRAGHINĂ, Daniel PEPTENATU, Cristian DRAGHICI \\ University of Bucharest, Romania
}

\begin{abstract}
In the strategies of regional development, an increasing importance is given to identifying the possibilities of endogenous development which, besides the exogenous impulses, contributes to an optimal development of local economies. Gorj County is one of the counties which recorded a major economic decline following the restructuring of economic activities. These counties need interventions at the strategic level, in order to identify the development alternatives, based on the capitalization of local resources. Following the analysis of the relation between the enterprise initiative and development, the way in which it has become fundamental for the development of a geographical space was clearly underlined. The analysis of this determination offers a well documented scientific support to the local and central authorities; this support regards the development of the enterprise initiative in territorial profile and, on this basis, it offers concrete solutions, based on decisional chains, which will have as a result the attenuation of the imbalance within the territorial profile. The endogenous development of the territorial systems may contribute to the sustainability of the cohesion process at local, regional and national levels.
\end{abstract}

Key Words: endogenous development, rural changes, territorial dynamics, Gorj

\section{Introduction}

An important component of the rural development strategies is the identification of possibilities to capitalize the resources of the territory. If the innovations and the capitalization good practices are assimilated, they will lead to an optimal development of local economies.

The mining areas from Gorj county that are affected by restructuring nowadays need interventions at strategic level, in order to identify the alternatives of development based on the capitalization of local resources.

An important concern for decision factors is the identification of poles of development able to transmit the innovation and good practices to the territorial systems and those will lead, in time, to shaping new territorial competences. The construction of a polycentric network is indispensable for the process of endogenous development; this type of development is the result of information exchange at the network level. Information is vital within the process of capitalizing local resources.

The endogenous development of the territorial systems affected by the decline of the main activities is due to the development of the culture and enterprise sector. Supporting the enterprise initiative represents an important direction of action within the territorial management, 
ensuring an optimal balance of the economic subsystem. Sustaining the enterprise sector may be considered a chain link of the decisional chain, aimed to redirect the evolution of the territorial system. Shaping the intervention at the level of the territorial system with the aim of developing the enterprise sector may be done with help from the decisional chains model, a theoretical model which shows the degree in which a decision has had the expected results. The advantage of this model is that it offers a clear image upon the possibilities of correcting the decisional impulses that have not med the decision factors' expectations. The model of decisional chains helps the decision factors to graduate the intervention depending on the needs of the system.

The decisional chains represent well structured sets of decisions and decisional consequences oriented according to the strategy of territorial management. A suggestive representation method is the decision graph which underlines the initial decisional impulses (IDI), the forecasted and un-forecasted decisional consequences (DC), as well as the order in which they operate.

The initial decisional impulse or impulses represent the starting point in the process of territorial management, their initiation being preceded by an analysis at nano-structural level which identifies the variable components of the system.

The forecasted decisional components are the expected finalities and they must be situated within a set of optimal alternatives. A wrong decisional impulse may lead to un-forecasted evolutions (CDN) which force new decisional impulses $\left(I_{n}\right)$. An optimal decisional chain is when the IDI-CDP cycle is the shortest possible.

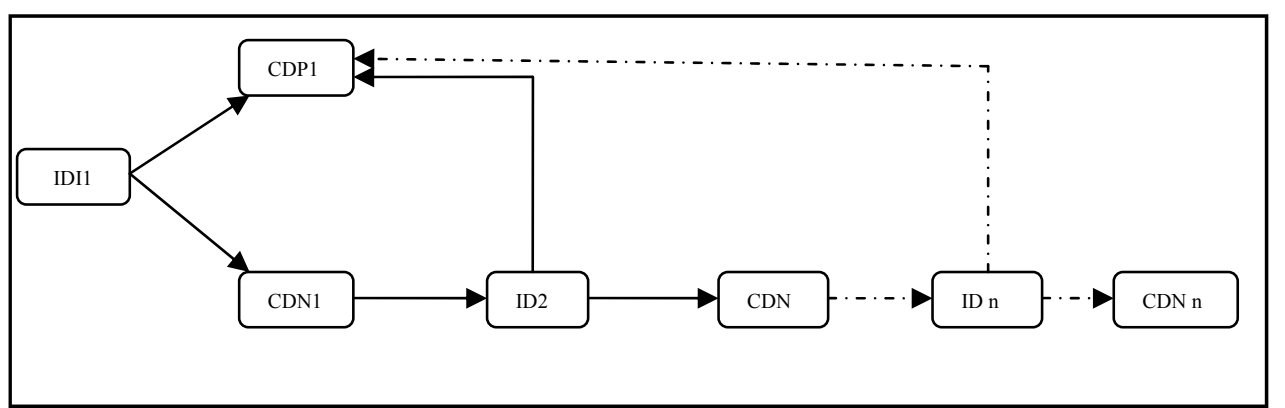

Fig.1.- The decisional chain structure

Following the analysis of the relation between the enterprise initiative and development, the way how the enterprise sector becomes fundamental for the development of a geographical area was clearly highlighted. The analysis of this determination offers local and central authorities a well documented scientific support regarding the development of the enterprise initiative in territorial profile and, therefore, it offers concrete solutions, based on decisional chains, which will lead to the attenuation of the territorial disparities. At the same time, a clear image of the territorial components which need support in order to sustain development is provided as well.

\section{The development of the mining activities in Gorj County}

Gorj County holds over $70 \%$ of the inferior coal stocks in Romania, most of the coal deposits being situated in a coal pit and easily to exploit (the average thickness of the gangue layers is 
of 3-4 metres, and the coal layers are at a slope of less than 5-10\%).

The exploitation of brown/ wood/ earth coal began in 1995 in the Rovinari Basin, for the first time in our country by the "ground level" exploitation method, with the opening of the the experimental pit Balta Unchiaşului. The favourable results obtained, as well as the important volume of pit workable deposits from the Rovinari Basin, opened new perspectives for the development of the brown coal production in this basin, using the "ground level" exploitation method. In parallel with the activity from the Rovinari Basin, the activity of capitalizing the brown coal deposits from Oltenia also began in the Motru Basin, the second biggest basin of the country, situated in the western sector of the region. The geological researches identified new brown coal deposits in this region, and, therefore, the activity of extracting in pits began in both Motru and Jilt Basins in 1976.

Along the time new mines and pits were opened and used, and today over $95 \%$ of the surface with industrials deposits is being exploited (quarried). Also, in the same period some production capacities ceased to function, as the deposits were extracted entirely, and the ground surfaces which had been used were released from technological charges totally. The exploiting method is organised in three main coal basins: Motru, Jilt, and Rovinari (Fig.2).

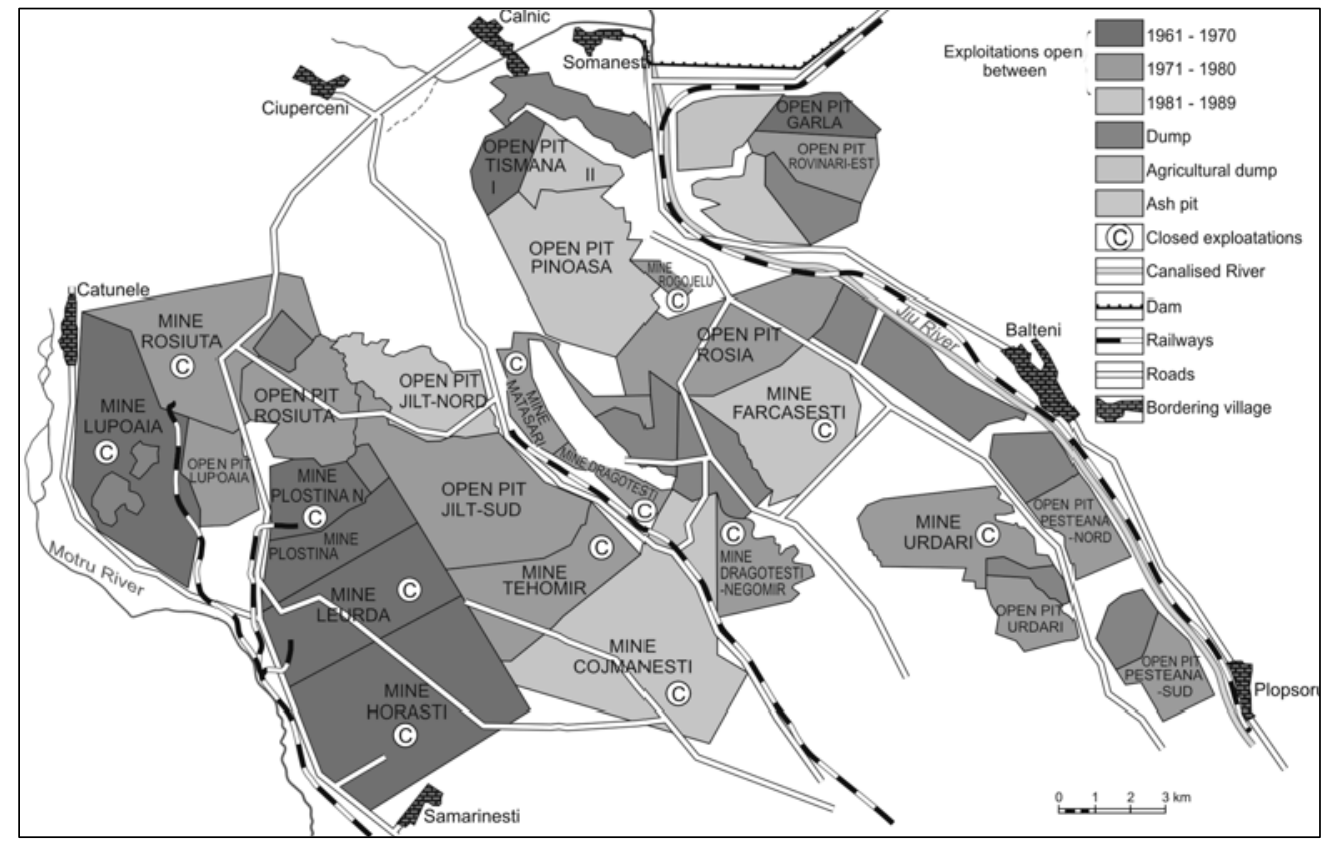

Fig. 2 - Mines and open pits in Gorj county

The economic crisis from the period starting after 1990, together with the deficient management of the financial and human resources, to which the request for energy from the internal market was added, led to the constant decrease of the coal quantity extracted from the coal basins, from $37,013,000$ tons in 1989 to $19,000,000$ tons of brown coal in 1998, and then it increased to $29,000,000$ tons in 2007. 
Taking into account the fact that the brown coal production from Gorj County contributes to the about $35 \%$ of the yearly production of electric energy and $80 \%$ of the energy based on coal is produced here, the important role that Gorj still has at national level can be easily noticed, even after restructuring.

The restructuring of the mining activity led to the emergence of a deficit of jobs and to shaping some major social imbalances. The diminuation of these imbalances may be done based on identifying the development alternatives based on the capitalization of local resources.

\section{The territorial impact of the restructuring of the mining activities upon the local economies}

The local importance of restructuring the mining activity is first given by the multitude of the exploitation points, which are situated near some rural and urban localities, and which have represented, for a long period of time, the only activity offering well paid jobs. Restructuring also meant the conservation of some mines, inclusively their closing. This fact influenced negatively the dependent territorial systems. This direct influence reflects upon the level of the income of the natives, who had been specialised in mining, and upon the possibility of rural use of the surplus of work power.

The very limited capacity of agriculture and of new small and medium length enterprises to use in the perspective the local work force lead to the search of new ways of sustaining the alternatives of socio-economic development of the localities included in this area.

The reduction of the mining activity has a distinct impact upon the towns with this function, as both in the case of Motru, as well as Rovinari, most of the population was attracted from other localities, usually situated at large distances. Therefore, sending the respective people in the agriculture field is almost impossible (the field crisis is much accented), and the only alternative remainsto develop the services and the small productive enterprises.

At regional level, the impact is also strong, as not only the localities situated within 3,000 square kilometres from the mining exploitations are directly or indirectly affected, but also the side areas, which have provided work force for the respective activities, and where big thermo-electric plants were installed. In this latter situation are the localities Turceni, Craiova, Rovinari, Govora, Halânga, where the power stations function much under their installed capacity, due to the dramatic decrease of the electricity use at national level and due to starting the nuclear power plant from Cernavoda, which became an important competitor.

The work force within the industrial units counted in 1991, over 40,000 people, which represented $62 \%$ of the total number of employees in the total of the industrial units in the region. The economic restructuring after 1989 led to a decrease of the employees' number in the region of approximately 22,000 people on the whole, and of over 16,000 for the industrial sector. The economic changes appeared after 1991 led to major changes in the total number of employees; for the entire region, there was a 18\% decrease, but for the rural area the decrease was $32 \%$, whereas in the urban area the decrease it was only $3 \%$. This higher decrease from the rural area is explained by the almost total disappearance of employees from agriculture, as a result of the dispatch of agricultural cooperatives and of the mechanisation units.

The changes among the employees from the extracting industry represented $73 \%$ of the 
number of the employees in the industry field, the biggest weights being at Mătăsari, Fărcăşeşti, Drăgoteşti, Bâlteni. The presence of the two power plants of great power, Turceni and Rovinari, led to high weights of the employees from the branch of the electric and thermic energy industry for these localities, $91 \%$ and respectively $31 \%$. This way, the number of employees from the extracting industry decreased in the interval 1991-2005 in the entire region for all the localities situated in the mining areas (Fig.3).

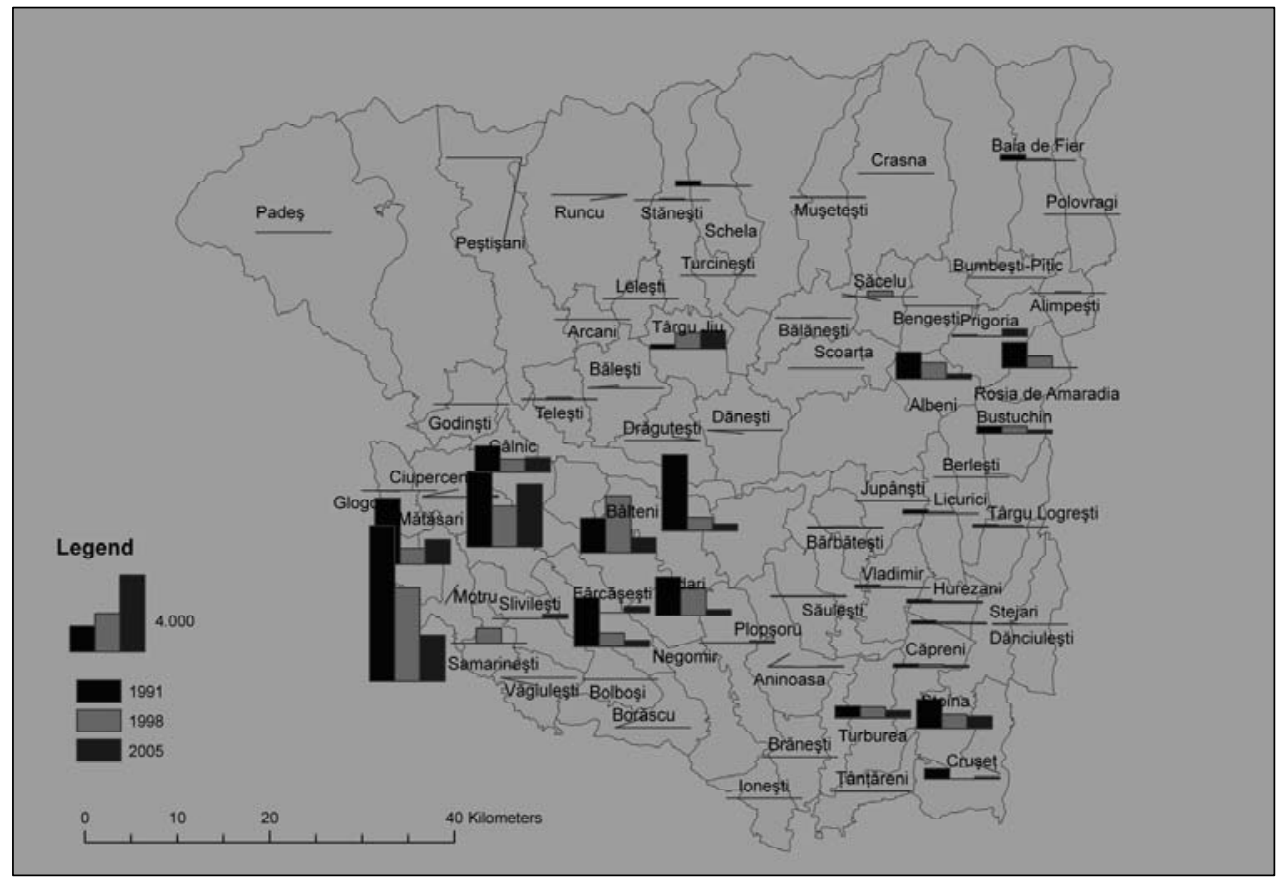

Fig. 3 - The evolution of the number of employees from the extracting industry

The changes among employees from the extracting industry are also reflected by the evolution of the unemployment rate in the entire county. Thus, the unemployment rate for Gorj County was $5.7 \%$ in 2007 , a little higher than the average of the South-West Region $(5.5 \%)$ and the national average $(5,1 \%)$. In the period 2005-2007, the un-employment rate decreased under $6 \%$, getting close to the national average, but there were important distinctions between the urban area (4.4\%) and the rural area, where the value was $7.4 \%$.

The territorial distribution at the county level shows important differences between the rural areas from the eastern and southern part of the county and the central-northern area and from the immediate neighbourhood of the town Târgu-Jiu. Thus, the highest values are recorded in Pades and in the neighbourhood of the coal basins Motru-Rovinari. The unemployment rate also records very high values, over the regional and national average, at the level of the young and feminine population.

There are two important periods in the analysis of the unemployment rate evolution, compared to the national trend for the interval 1990-2007 in Gorj County: the first is before 1997, when the recorded value was below the national average (fluctuated between 2-4 \%), and the second 
after 1997, when, once the restructuring of the mining sector took place, the unemployment rate increased overthe national average, a situation which is found today as well.

The development of the agricultural activities represents an important alternative, but there are numerous restrictions, represented by the degradation of soils as a result of mining and of the delay of the rehabilitation of the soils released from technological charges. The development of some agricultural farms in the areas that were agriculturally rehabilitated may be the objective of some economic strategies at European level.

Curently, two kinds of agricultural activities are used in the area: a primary activity, represented by vegetal and animal production, and a secondary activity, represented by the industrial processing of some part of this production. The development of mining in this region reduced the agricultural surfaces very much in the past, but when the decline of the mining activities came in place, some of these surfaces were given back to agriculture. In time, the surfaces which had been given back to agriculture proved to be less efficient, having a very low productivity, due to the poor soil and, even more, they were exhausted and affected by erosion. In addition, the reduced financial possibilities of the rural area homesteaders who do not allow mechanisation, and the reduced degree of fertility, elements which impose the use of subsistence agriculture, in most part of the region.

The width of the economic activities and their type represent an element which usually correlates with the degree of population of a territory. Along the time, the main traditional economic activities were agriculture and local forestry, which harmonised with the ecological potential, but in the last four decades there were registered extremely violent mutations, caused especially by mining activities. Once this sector developed (in the year 1960 the coal exploitations intensified, initially in the Rovinari area), about a quarter of the surface was directly affected by the coal exploitations, and almost $80 \%$ indirectly.

From the beginning of the mining activities since the end of 2006, in the coal basin Motru-JiltRovinari over 12.500 hectares of land were withdrawn from the economic circuit, for different specific activities, from which 10.457 hectares were agricultural areas, and 199 hectares were forest areas (Fig. 4).

The loss of identity by rural settlements can be appreciated also by the number of private homesteaders which were expropriated, as a result of the works of scraping and the adjacent hydro-technical works. Therefore, for the Rovinari basin 2,224 homesteads were laid out, in the Jilt basin, 752, and in the Motru basin, 752 homesteads. The volume of these interventions, to which the sacred value of the cemeteries (917) and the cultural and spiritual value of the destroyed churches (15) must be added, gives the real dimension of the unselective pressure in opposition with some immediate benefits.

The establishment (exploitation) of some pits and disaffected mines for tourism represents another important strategic direction, which, besides the graphic modeling or the landscape reconstruction of displaced habitats, could form an economic activity providing income. 


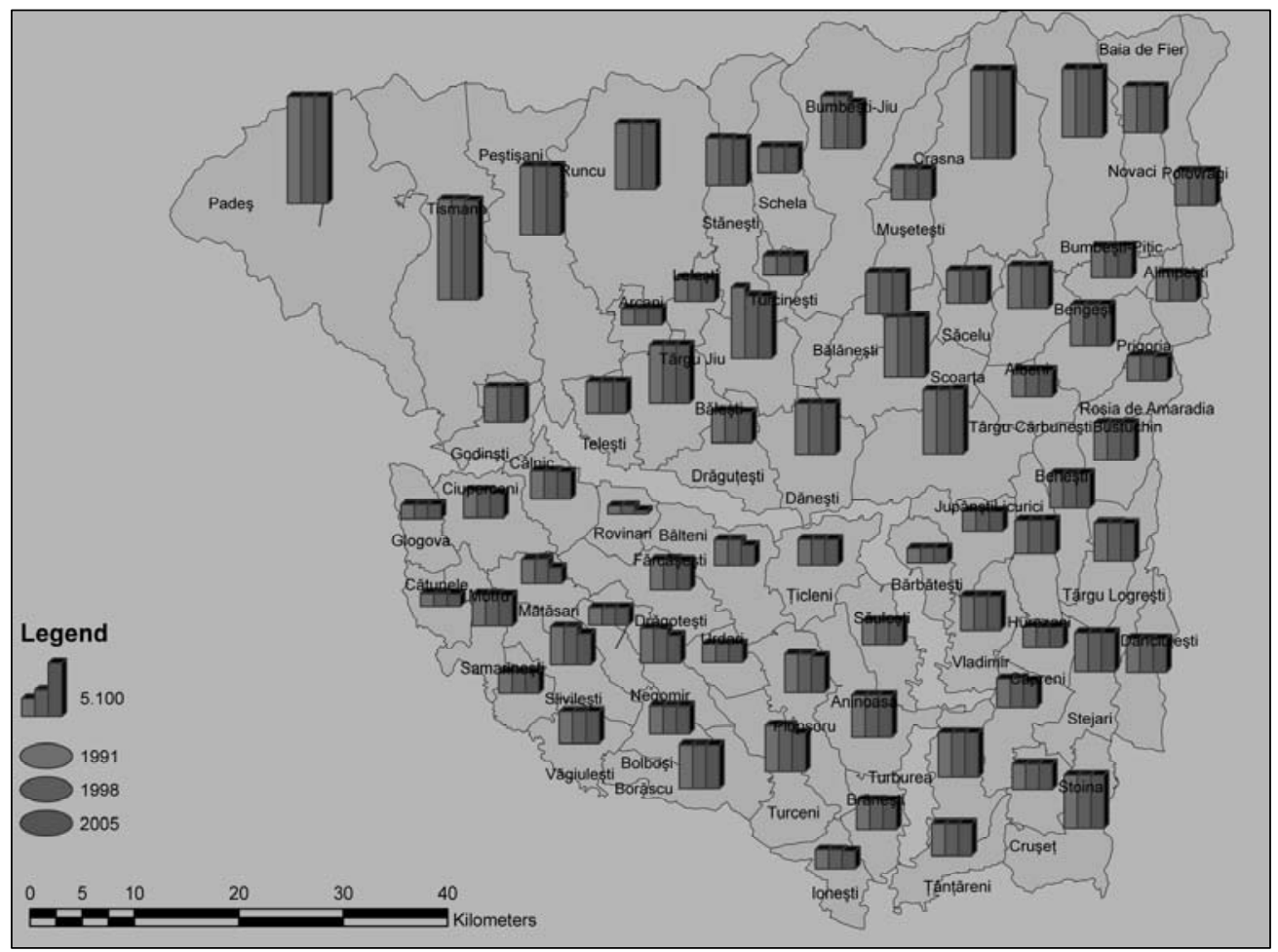

Fig.4 - The evolution of the agricultural surface

\section{Conclusions}

In revitalising the economic activities from the analysed area, a decisive role could be hold by the elaboration of some studies regarding the viability of the establishment of some small and medium size enterprises, insignificant today, specialised in activities which are connected or complementary to the activity of mining. These could be specialised in specific activities of environment restoration or of capitalisation of some local resources. Therefore, among the possible directions of developing small and medium size enterprises, the following can be identified:

- the recuperation and return to the productive circuit of the lands taken out from the exploitation circuit, as a result of the exhaustion of the brown coal resources;

- the use of waters resulted from the processes of drainage of some mining perimeters,

in local networks of irrigation, washing stations or even water alimentation/ supplying;

- the fertilization of lands/ soils by using the coal dust;

- the use of quartz sands situated at the top of brown coal deposits of Huşnicioara pit;

- providing for the population preliminarily sorted coal, in containers or in packages;

- starting some industrial or handwork activities within some mining areas where the activity was closed (different activities can be organized here, such as obtaining some protection equipments or materials of construction, using the raw material from scrapings, obtaining some materials for the mining activity in the area - ventilation pipes, wire nets, beams, etc, the recuperation of materials - metals, old band carpets, setting 
up fungi farms in some underground galleries; organising activities in order to reduce pollution (dust, gas emissions, noise, wastewaters etc);

- the elaboration by authorities of some projects of touristic facilities of the mining exploitations.

The revitalisation of economic activities can be viable if the territorial management strategies take into account the construction (building) of some polycentric networks of settlements, as the local poles of development and the centres of growth have a special role in the capitalization of local resources. In order to attract investments within the secondary poles of growth, the following courses of actions are proposed:

The endogenous development of restructured mining areas can be possible if the decision factors elaborate viable strategies of territorial development, which, by the infusion of innovation and good practices, will contribute efficiently to the capitalization of local resources.

\section{Bibliography}

BRAGHINĂ C. (2000), Dealurile piemontane dintre Valea Motrului şi Valea Gilortului. Studiu de geografie umană, cu privire specială asupra organizării teritoriului, Edit.Tehnică, Bucureşti.

BRAGHINĂ C. PEPTENATU D., DRĂGHICI C. (2008), The role of polycentric development in the management of severely disadvantaged areas, în Revista Geographica Timisiensis, Timişoara.

CLAVAL P. (1993), Initiation al la geographie regionale, Paris, Nathan.

COOKE P., MORGAN K. (2000), The associational economy: firms, regiona and innovation, Oxford University Press, New York.

DAUPHINE A. (1999), Une theorie des disparites geographiques, RERU, 5.

DE FIGUEIREDO E.V.S. (1998), La methote statistique dans la definition de regions heterogenes dans des espaces geographiques, RERU, 4.

IACOB Gh., IANOŞ I. (1980), Zona carboniferă Motru-Jiu (Rovinari), considerații economico-geografice, Terra, 4, p.19-22.

IANOŞ I. (1998), The influence of economic and regional policies on migration in Romania, Romania: Migration, Socio-economic Transformation and Perspectives of Regional Development (ed. Wilfried Heller), Sudosteuropa-Studien 62, p.55-76.

IANOŞ I. (1997), Individualizarea şi analiza disparitatilor intraregionale. Aplicatie la judetul Alba, Comunicari de geografie, II.

IANOŞ I. (2000), Sistemele teritoriale, Editură Tehnică, Bucureşti.

IANOŞ I., (1987), Some elements of settlement systems analysis, Revue Roumanie de Geologie, Geophysique, Geographie, Geographie, tome 31.

IANOŞ I., (1997), Industria, element şi factor de presiune în organizarea spațiului, AUV, Geografie, vol. VII, Timişoara.

IANOŞ I., (2000), Potentialul economic al teritoriului şi dezvoltarea sectorului antreprenorial în Romania, Terra, 2.

IANOŞ I., HUMEAU Jean-Baptiste (2000), Teoria sistemelor de asezari, Editura Tehnică, Bucureşti.

JULA D., JULA Nicoleta (1998), Dinamica dezechilibrelor în dezvoltarea regională, Oeconomica, 3-4.

LALATKA R., BISHOP J. (2000), Rolul incubatoarelor de afaceri în dezvoltarea economică. O primă evaluare efectuată în țările în curs de dezvoltare şi în țările cu economie în tranziție, EdituraAll Beck, Bucureşti.

LUCEY T. (2001), Tehnici cantitative, Editura Tehnică, Bucureşti. 
MATEI Lucica (1999), Managementul dezvoltării locale, Editura Economică, Bucureşti; MERENNE-SCHOUMAKER Bernadette (1994), Les disparitites et les dynamiques territoriales. Introduction methodologique, BSG, Liege, 30.

PEPTENATU D., DRĂGHICI C., PINTILII R.(2006), Considerations theoretiques regardant le management teritorial fonde sur la theorie des poles de croissance, Lucrările Seminarului International de Gestiune a Oraşelor, M'Sila, Editura M'Sila, Algeria.

PEPTENATU D., TĂLÂNGĂ C., PINTILII R. (2008), Rolul sectorului antreprenorial în tratamentul ariilor profund dezavantajate, in Comunicări de geografie, Editura Universitătii din Bucureşti, p.355.

TĂLÂNGĂ C., PEPTENATU D., STOICA ILINCA-VALENTINA (2008), Functional structure of severely disadvantaged areas in Gorj County in Geographica Timisiensis, Timişoara. 